\title{
Early-life conditioning strategies to reduce dietary phosphorus in broilers: underlying mechanisms
}

\author{
A. S. Valable ${ }^{1,2}$, M. P. Létourneau-Montminy ${ }^{1}$, S. Klein ${ }^{3}$, L. Lardic ${ }^{2}$, F. Lecompte ${ }^{4}$, S. Metayer-Coustard ${ }^{2}$, \\ N. Même ${ }^{2}$, G. Page ${ }^{5}$, M. J. Duclos ${ }^{2}$ and A. Narcy ${ }^{2} *$ \\ ${ }^{1}$ Animal Sciences Department, Université Laval, 2425 rue de l'Agriculture, QC, Canada G1V 0A6 \\ ${ }^{2}$ INRAE, Université de Tours, UMR BOA, 37380 Nouzilly, France \\ ${ }^{3}$ MiXscience, Centre d'affaires Odyssée, ZAC Cicé Blossac, 35172 Bruz, France \\ ${ }^{4}$ Plateforme CIRE, service imagerie - UMR 0085 PRC, INRA centre val de Loire, 37380 Nourilly, France \\ ${ }^{5}$ Troum Nutrition Agresearch, Ontario, Canada
}

(Received 12 May 2020 - Accepted 21 May 2020)

Journal of Nutritional Science (2020), vol. 9, e28, page 1 of 9

doi:10.1017/jns.2020.17

Abstract

Chickens adapt to P and Ca restriction during the very first days of life by improving P utilisation efficiency. The present study was built to identify the mechanisms underlying this adaptive capacity, and to identify the optimal window of application of the restriction (depletion). A total of 1600 Cobb $500^{\mathrm{TM}}$ male broilers were used. During each phase (from age 0 to $4 \mathrm{~d}, 5$ to $8 \mathrm{~d}, 9$ to $18 \mathrm{~d}$ and 19 to $33 \mathrm{~d}$ ), the animals received either a control diet ( $\mathrm{H}$ ) or a restricted diet $(\mathrm{L})$ with reduced levels of non-phytate $\mathrm{P}(\mathrm{nPP})$ and $\mathrm{Ca}$ (between -14 and $-25 \%$ for both) with four dietary sequences: HHHH, HLHL, LHHL and LLHL. None of the feeding strategies affected growth. Tibia ash content at day 4 and 8 was impaired when the L diet was fed from 0 to 4 and 5 to $8 \mathrm{~d}$, respectively $(P=0.038$ and $P=0.005)$. Whatever the early restriction period or length between 0 and $8 \mathrm{~d}$ of age, the mineralisation delay was compensated by day 18. This was accompanied by an increased mRNA expression of the Ca transporter, CALB1, and an increased apparent ileal digestibility of $\mathrm{Ca}$ at day $8(P<0.001)$. This adaptation was limited to the starter phase in restricted birds. No effect was seen on $\mathrm{P}$ transporters mRNA or protein expression. In conclusion, birds adapted to mineral restriction by increasing $\mathrm{Ca}$ and nPP utilisation efficiencies. Depletion-repletion strategies are promising in improving the sustainability of broiler production but need to be validated in phytase-supplemented diets.

Key words: Broiler chickens: Feeding strategies: Calcium: Phosphorus: Adaptation

Nutritional strategies for improving the efficiency of $\mathrm{P}$ use by birds could be implemented to reduce P excretion and avoid P overfeeding. The reduction of dietary P level is possible if the Ca level is simultaneously decreased ${ }^{(1)}$ due to lower propensity for Ca-phosphate and Ca-phytate complexes in the digestive tract. This strategy is particularly interesting in the finisher phase where feed intake and consequently $\mathrm{P}$ excretion are high. In addition, broilers fed diets deficient in $\mathrm{Ca}$ and nonphytate $\mathrm{P}(\mathrm{nPP})$ during an early phase of growth (depletion) exhibit better $\mathrm{P}$ and $\mathrm{Ca}$ utilisation and are able to compensate for bone mineralisation ${ }^{(1,2)}$. A more complete understanding of the mechanisms involved in this adaptation is required to efficiently use this kind of strategy.

Intestinal enterocytes are constantly exposed to fluctuations in $\mathrm{Ca}$ and/or P availability. These fluctuations have been proven to affect gene and protein expression and the activity of transporters through a mechanism driven by parathormone and vitamin $\mathrm{D}_{3}^{(3)}$. At low $\mathrm{nPP}$ and $\mathrm{Ca}$ intake, birds have

Abbreviations: AID: apparent ileal digestibility; BW: body weight; H: high non-phytate P and Ca; HU: Hounsfield units; L: low non-phytate P and Ca; nPP: non-phytate P; PPdisp: disappearance of phytate $\mathrm{P}$.

* Corresponding author: A. Narcy, email agnes.narcy@inrae.fr 
been shown to adapt by increasing mRNA expression of $\mathrm{Ca}$ transporters: $C A L B 1^{(4)}, A T P 2 B 1^{(5,6)}$ and $S L C 8 A 1^{(6)}$ and $\mathrm{P}$ transporters: SLC $34 A 2^{(7,8)}$ and SLC20 $A 1^{(9)}$ in the small intestine. So far, the majority of these studies have focused on the mRNA expression of no more than three genes at a time, focusing mainly on either $\mathrm{Ca}$ or $\mathrm{P}$ transporters. Moreover, to our knowledge, only a few studies have measured the impact of these diets on the protein expression of $\mathrm{P}^{(9,10)}$ and $\mathrm{Ca}^{(4,6)}$ transporters in broilers.

Ashwell \& Angel ${ }^{(11)}$ observed that birds fed a deficient diet during the first $90 \mathrm{~h}$ of life improved $\mathrm{P}$ and $\mathrm{Ca}$ apparent absorption compared with control birds. This adaptation was apparent from $90 \mathrm{~h}$ and remained even if the birds were fed an adequate diet from $90 \mathrm{~h}$ to $38 \mathrm{~d}$ of age. It was linked to an increase in SLC34A2 mRNA expression. Thus, those authors made the hypothesis that an imprinting of the birds was possible, involving a long-term adaptation in gene expression. A recent study (MM Van Krimpen, E Willems and HJ Van Harn, unpublished results) failed to observe such a long-term adaptation in birds fed a deficient $\mathrm{Ca}$ and $\mathrm{nPP}$ diet from 0 to $4 \mathrm{~d}$ of age, which showed decreased $\mathrm{P}$ and $\mathrm{Ca}$ pre-caecal digestibility at day 37, without any variation in the mRNA expression of CALB1, ATP2B1 and SLC34A2. These conflicting results suggest a lack of knowledge about the degree of dietary nPP and Ca reduction, the timing and/or the duration of the depletion required to induce a long-term adaptation in the birds.

The first objective of this experiment was to identify the optimal depletion-repletion strategies. Several conditions (duration and timing) were tested during the depletion phase with the hypothesis that the birds could undergo a long-lasting adaptation with an improved efficiency in mineral utilisation while maintaining growth and bone mineral status. The second objective was to identify and understand the mechanisms related to the adaptation with the hypothesis that it could involve modifications in $\mathrm{Ca}$ and $\mathrm{P}$ duodenal transporter mRNA and/or protein expression.

\section{Materials and methods}

The experiment was conducted under the guidelines of the French Ministry of Agriculture for Animals (Paris, France, authorisation 1153-2015071514404178) at PEAT INRA Poultry Experimental Facility (2018, https://doi.org/10. 15454/1.5572326250887292E12).

\section{Experimental diets}

The experimental period was divided into four phases: from 0 to 4,5 to 8,9 to 18 , and 19 to $33 \mathrm{~d}$ of age. All experimental diets were based on maize, soyabean meal and wheat. During each phase, the birds received either a high $(\mathrm{H})$ or a low $(\mathrm{L})$ diet (Table 1). The $\mathrm{Ca}$ and nPP levels in the $\mathrm{H}$ diets were in accordance with the breeder recommendations ${ }^{(12)}$ between 0 and $4 \mathrm{~d}$ of age and were at the levels used in commercial conditions for the other phases. The $\mathrm{L}$ diets were designed to contain between 14 and $25 \%$ lower $\mathrm{Ca}$ and nPP levels compared with the $\mathrm{H}$ diet, depending on the phase. For the first three phases, the $\mathrm{Ca}$ content was, respectively, 1.00, 0.92 and $0.77 \%$ in the $\mathrm{H}$ diets and $0.77,0.70$ and $0.66 \%$ in the $\mathrm{L}$ diets. Likewise, nPP contents were, respectively, 0.45, 0.45 and $0.35 \%$ in the $\mathrm{H}$ diets and $0.35,0.32$ and $0.30 \%$ in the $\mathrm{L}$ diets. The last phase was divided into two dietary periods: 19 to $28 \mathrm{~d}$ of age and 29 to $33 \mathrm{~d}$ of age. The $\mathrm{Ca}$ and nPP contents in the $\mathrm{H}$ diet were, respectively, 0.64 and $0.29 \%$ from 19 to $28 \mathrm{~d}$ of age and then 0.55 and $0.25 \%$ from 29 to $33 \mathrm{~d}$ of age. The $\mathrm{Ca}$ and $\mathrm{nPP}$ contents in the $\mathrm{L}$ diet were, respectively, 0.53 and $0.24 \%$ from 19 to $28 \mathrm{~d}$ of age and then 0.44 and $0.20 \%$ from 29 to $33 \mathrm{~d}$ of age. Diets in each phase were combined to form four dietary sequences: (1) HHHH; (2) HLHL; (3) LHHL; and (4) LLHL (see Table 2). The first treatment was the control. Treatments 2, 3 and 4 were designed to study the timing and duration of the first depletion (from 0 to 8 or 0 to 4 or 5 to $8 \mathrm{~d}$ of age). During the finisher phase, feed intake and $\mathrm{P}$ excretion are at their highest levels. Therefore, the $\mathrm{P}$ and $\mathrm{Ca}$ levels were reduced during this period based on a previous study indicating the possibility of a complete recovery of the birds at the bone level ${ }^{(1)}$. Calcium carbonate $\left(\mathrm{CaCO}_{3}\right)$ and dicalcium phosphate $\left(\mathrm{CaHPO}_{4}\right)$ were added to the diets to adjust the $\mathrm{Ca}$ and nPP content. Titanium dioxide $\left(\mathrm{TiO}_{2} ; 0.3 \%\right)$ was added to the diets from 5 to $18 \mathrm{~d}$ of age and from 28 to $33 \mathrm{~d}$ of age as an indigestible marker to enable determination of $\mathrm{P}$ and Ca apparent ileal digestibility (AID). Diets and water were distributed ad libitum. Diets were distributed as medium crumbs from 0 to $4 \mathrm{~d}$ of age and as medium pellets after day 5 .

\section{Birds and management}

A total of 1600 1-d-old male broilers (Cobb $500^{\mathrm{TM}}$ ) were raised from 0 to $35 \mathrm{~d}$ of age. At their arrival, broilers were weighed and randomly allocated to thirty-two pens (eight pens per treatment). The study consisted of a randomised block design with eight blocks of four pens each $\left(3 \mathrm{~m}^{2}\right.$ per pen). In each block, pens were randomly allocated to a treatment (400 birds per treatment). The room temperature was settled at $33^{\circ} \mathrm{C}$ upon arrival and decreased progressively to reach $20^{\circ} \mathrm{C}$ at day 35. Birds were kept under $24 \mathrm{~h}$ light on day 1, $23 \mathrm{~h}$ from day 2 to day 4 and $18 \mathrm{~h}$ thereafter. The broilers were weighed individually at days $0,8,18$ and 33 (mean weight 2356.1 (SD 230.2) g). Feed intake per pen was recorded for each phase. Pre-caecal digesta samples from the distal half of the ileum (defined as extending from Meckel's diverticulum to the ileo-caecal junction) were collected from eight birds per pen (eight pens per experimental diet) at days 8,18 and 33 after pentobarbital injection. Digesta samples were pooled in order to achieve eight pools of eight birds for each treatment. Out of those sixty-four broilers per treatment, twelve broilers per treatment were used to collect intestinal tissue samples immediately after death. The duodenum was isolated and thoroughly washed in ice-cold PBS solution. A 5-cm medial sample was snap-frozen and scraped into liquid $\mathrm{N}_{2}$ before storage at $-80^{\circ} \mathrm{C}$. The right tibia was collected from twelve birds per treatment at day 4, day 8, day 18 and day 33. At day 33, ten additional birds per treatment were euthanised and stored at $-20^{\circ} \mathrm{C}$ until scanning. The litter from four pens per treatment was weighed at the beginning and the end of the experiment. On the last day of the experiment, a $1.5 \mathrm{~kg}$ sample was taken after mixing the whole litter to estimate P excretion. 


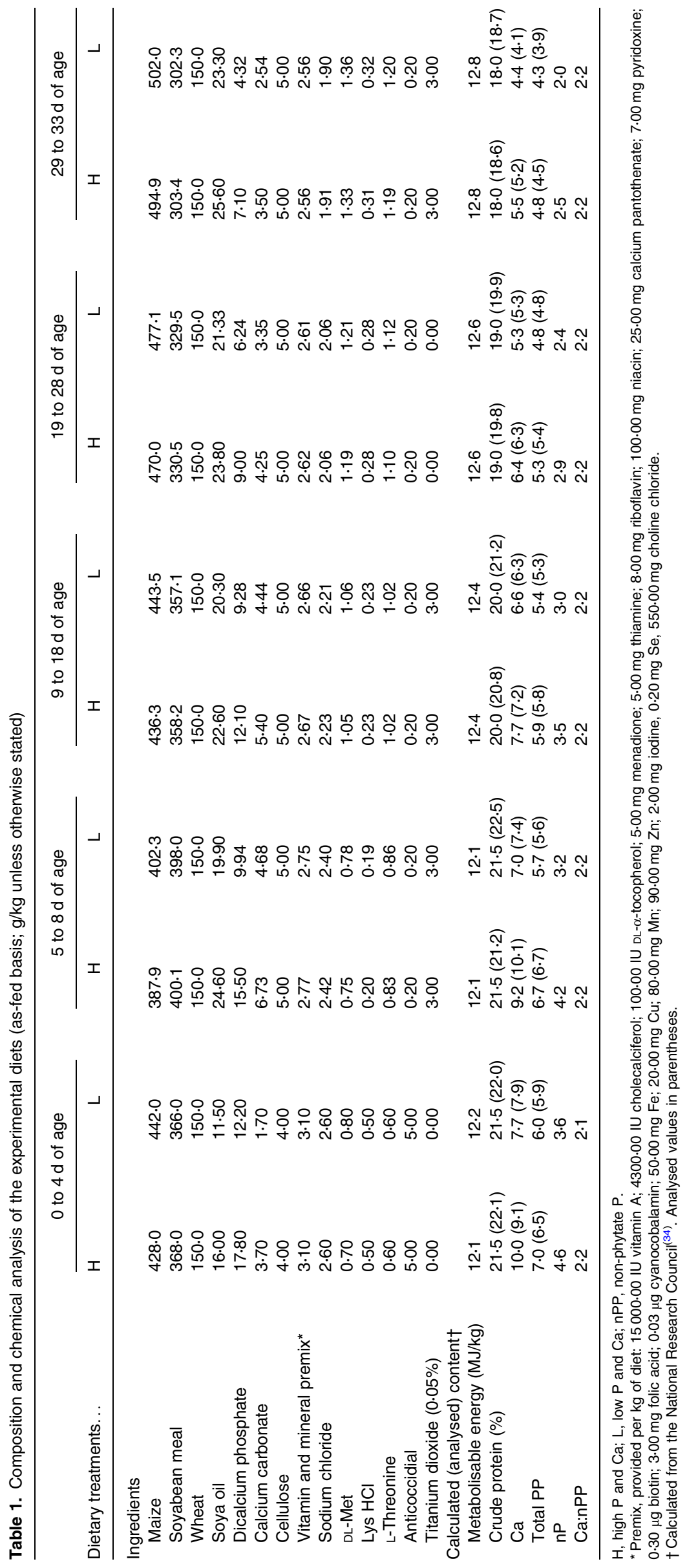


Table 2. Experimental design

\begin{tabular}{lcccc}
\hline & \multicolumn{4}{c}{ Diets received per phase } \\
\cline { 2 - 5 } Treatment name & 0 to $4 \mathrm{~d}$ & 5 to $8 \mathrm{~d}$ & 9 to $18 \mathrm{~d}$ & 19 to $33 \mathrm{~d}$ \\
\hline HHHH & $\mathrm{H}$ & $\mathrm{H}$ & $\mathrm{H}$ & $\mathrm{H}$ \\
HLHL & $\mathrm{H}$ & $\mathrm{L}$ & $\mathrm{H}$ & $\mathrm{L}$ \\
LHHL & $\mathrm{L}$ & $\mathrm{H}$ & $\mathrm{H}$ & $\mathrm{L}$ \\
LLHL & $\mathrm{L}$ & $\mathrm{L}$ & $\mathrm{H}$ & $\mathrm{L}$ \\
\hline
\end{tabular}

$\mathrm{H}$, high non-phytate $\mathrm{P}$ and $\mathrm{Ca}$; L, low non-phytate $\mathrm{P}$ and $\mathrm{Ca}$.

\section{Computed tomography scans}

The carcasses at day 33 were scanned using a clinical computed tomography machine (Somatom Definition AS128; Siemens) with scan parameters set at $140 \mathrm{kV}$ tube voltage and $500 \mathrm{mAs}$ current. The image acquisition mode was a matrix size of $32 \mathrm{~cm}$ and $512 \mathrm{px}$ and a resolution of $650 \mu \mathrm{m}$. The images were converted into DICOM (Digital Imaging and Communications in Medicine) format for analysis using SINGO.VIA (Siemens) software. Bone mineral density was estimated on the right tibia. The bone mineral density was given in Hounsfield units (HU) by the scanner software and later converted to $\mathrm{g} / \mathrm{cm}^{3}$ using a phantom (Electron Density Phantom (Model 062 M); Meditest). Total bone was defined in the intervals $200-3000 \mathrm{HU}$ according to Militist et al. ${ }^{(13)}$. Trabecular and cortical bones were defined in the intervals, respectively, of 200-800 $\mathrm{HU}$ and $801-3000 \mathrm{HU}$, according to Sherlock et al. ${ }^{(14)}$.

\section{Chemical and mechanical analysis}

Litter and ileal digesta samples were freeze-dried. DM was determined for right tibias $\left(103^{\circ} \mathrm{C}\right.$ for $\left.12 \mathrm{~h}\right)$ and diets $\left(103^{\circ} \mathrm{C}\right.$ for $\left.4 \mathrm{~h}\right)$. Samples of the diets, ileal contents, litters and tibias were ashed at $550^{\circ} \mathrm{C}$ for $12 \mathrm{~h}$. For mineral determination, $0.5 \mathrm{~g}$ of ashes were solubilised in $6 \mathrm{ml} \mathrm{HNO}_{3}$ and $4 \mathrm{ml}$ of $\mathrm{H}_{2} \mathrm{SO}_{4}$ and treated by microwave (room temperature to $210^{\circ}$ $\mathrm{C}$ for $20 \mathrm{~min}$ and at $210^{\circ} \mathrm{C}$ for $10 \mathrm{~min}$; ETHOSUP, Milestone) and then diluted in $50 \mathrm{ml}$ of water. $\mathrm{Ca}, \mathrm{P}$ and Ti contents were analysed using an Inductive Coupled Plasma Optical Emission Spectrometer (ICP-OES, iCaP 7000 Series, ThermoScientific; method 990.08; AOAC International, 2006).

To further refine the effects on the pre-caecal digestibility of $\mathrm{P}$ when significant, phytate was measured in ileal contents using a commercial assay kit (Megazyme International) and the pre-caecal disappearance of phytate P (PPdisp) determined.

\section{RNA isolation and RT-PCR assay}

Total RNA isolation and real-time RT-PCR assay were performed as described previously in Rousseau et al. ${ }^{(1)}$. Concentration and quality of the extracted RNA were assessed by spectrophotometry from 230 to $280 \mathrm{~nm}$, using a Nanodrop 1000 spectrophotometer (Nanodrop Technology). The ratios 260:280 and 260:230 were between $1 \cdot 8$ and $2 \cdot 2$. The integrity of RNA was assessed by the migration of total RNA on a $1.5 \%$ agarose gel. The primers used targeted the following genes (Table 3): P transporters: solute carrier family 20 (phosphate transporter), member 1 (Gallus gallus (chicken)) (SLC20A1), solute carrier family $34(\mathrm{Na} /$ phosphate), member 2 (Gallus gallus (chicken)) (SLC34A2); Ca transporters: calbindin 1, $28 \mathrm{kDa}$ (Gallus gallus (chicken)) (CALB1), ATPase, $\mathrm{Ca}^{2+}$ transporting, plasma membrane 1 (Gallus gallus (chicken)) (ATP2B1), solute carrier family 8 ( Na/Ca exchanger), member 1 (Gallus gallus (chicken)) (SLC8A1). The primers used to study the expression of ATP2B1 and SLC $8 A 1$ have been previously described in Jonchere et al. ${ }^{(15)}$. The other primers were specifically designed using Primer BLAST (http://www.ncbi. nlm.nih.gov/tools/primer-blast/). Amplification products were checked by electrophoresis and further sequenced prior to real-time quantitative PCR analysis.

\section{Western-blot analysis}

Duodenal lysates were prepared as described in Coudert et al. ${ }^{(16)}$. Samples were denatured at $75^{\circ} \mathrm{C}$ for $10 \mathrm{~min}$ before loading $(80 \mu \mathrm{g}$ of protein) for migration on $10 \% \mathrm{SDS} /$ PAGE gels and then transferred to nitrocellulose membranes. Membranes were blocked in $5 \%$ fat-free milk/PBS, $0 \cdot 1 \%$ Tween for $1 \mathrm{~h}$ at room temperature. Membranes were incubated with antibodies against SLC20A1 (ab177147; Abcam ${ }^{\circledR}$ ) $1: 5000$ for $3 \mathrm{~h}$ and against CALB1 (ab25085; Abcam ${ }^{\circledR)}$ 1:500 overnight. Membranes were then washed several times and incubated for $1 \mathrm{~h}$ with goat anti-rabbit secondary antibodies (A21076, AlexaFluor $\AA$; Life Technologies). After stripping, membranes were incubated with anti-vinculin antibody (V9131; Sigma) 1:40 000 for $3 \mathrm{~h}$ and then incubated with rabbit anti-mouse secondary antibodies (A21065,

Table 3. Primers used for quantitative RT-PCR

\begin{tabular}{|c|c|c|c|c|c|}
\hline Name & $\begin{array}{l}\text { Gene } \\
\text { symbol }\end{array}$ & $\begin{array}{l}\text { Genbank } \\
\text { accession no. }\end{array}$ & Forward primer sequence $\left(5^{\prime} \rightarrow 3^{\prime}\right)$ & Reverse primer sequence $\left(5^{\prime} \rightarrow 3^{\prime}\right)$ & $\begin{array}{l}\text { Product } \\
\text { size }(\mathrm{bp})\end{array}$ \\
\hline $\begin{array}{l}\mathrm{Na} / \text { phosphate } \\
\text { co-transporter } 2 \mathrm{~b}\end{array}$ & SLC34A2 & NM_204474 & GTCCGTTCACTCTGTTGCCT & TGGGTCCTCTTCTTGCCTTG & 242 \\
\hline $\begin{array}{l}\text { Na-dependent phosphate } \\
\text { transporter } 1\end{array}$ & $S L C 20 A 1$ & XM_003642557 & AGGGCAGAAAGGCGTCAA & CGAGGAAGAAGAGAACAGCAGA & 104 \\
\hline Calbindin 1, 28 kDa & CALB1 & NM_205513 & CAGGGTGTCAAAATGTGTGC & GCCAGTTCTGCTCGGTAAAG & 215 \\
\hline $\begin{array}{l}\text { Plasma membrane } \\
\text { Ca-transporting } \\
\text { ATPase } 1\end{array}$ & ATP2B1 & XM_416133 & CTGCACTGAAGAAAGCAGATGTTG & GCTGTCATATACGTTTCGTCCCC & 130 \\
\hline $\mathrm{Na} / \mathrm{Ca}$ exchanger 1 & $S \angle C 8 A 1$ & NM 001079473 & GGATTGTGGAGGTTTGGGAAGG & CTGTTTGCCAGCTCGGTATTTC & 137 \\
\hline
\end{tabular}


AlexaFluor®; Life Technologies). Bands were visualised by IR fluorescence using an Odyssey ${ }^{\circledR}$ Imaging System (LI-COR Inc. Biotechnology) and quantified by Odyssey IR imaging system software (Application software, version 1.2).

\section{Calculations and statistical analyses}

The $\mathrm{P}$ retained in $\mathrm{g} / \mathrm{kg}$ body weight $(\mathrm{BW})$ produced was calculated per pen as the sum of $\mathrm{P}$ ingested in all phases in $\mathrm{g} / \mathrm{kg}$ $\mathrm{BW}$ produced minus the $\mathrm{P}$ excreted in the litter in $\mathrm{g} / \mathrm{kg} \mathrm{BW}$ produced. The $\mathrm{P}$ retention efficiency was calculated per pen as the $\mathrm{P}$ retained divided by $\mathrm{P}$ intake in $\mathrm{g} / \mathrm{kg} \mathrm{BW}$ produced per pen. The AID and PPdisp were determined using the following equation: AID or PPdisp $(\%)=100-\left(100 \times\left(\mathrm{Ti}_{\text {Diet }} \times\right.\right.$ $\left.X_{\text {Digesta }} /\left(\operatorname{Ti}_{\text {Digesta }} \times X_{\text {Diet }}\right)\right)$ where $T i_{\text {Diet }}$ is the Ti concentration of the diet, $X_{\text {Digesta }}$ the P, Ca or PP concentration of the ileal digesta, $\mathrm{Ti}_{\text {Digesta }}$ the $\mathrm{Ti}$ concentration of the ileal digesta, and $X_{\text {Diet }}$ the P, Ca or PP concentration of the diet. Determination of the sample size for the study population was based on a power calculation using the estimated mean and standard deviation (35.6 (SD 1.3) \%) for tibia ash content from a previous broiler study ${ }^{(1)}$. Consequently, it was estimated that in order to detect a change in tibia ash content of $4 \%$ at a significance level of $0 \cdot 05$, with a power of $90 \%$, twelve animals per group should be used. A randomised block design with eight blocks was used to test the effect of dietary treatments on growth performance with the pen as the experimental unit for all criteria, except for bone mineralisation where the bird was the experimental unit. Dietary treatment was included in the model as a fixed effect and the block as a random effect. ANOVA were performed on the studied variables for each of the feeding phases using the MIXED procedure of SAS (version 9.2, 2002; SAS Institute Inc. ${ }^{(17)}$ ) after the normality of the variables was checked; multiple mean comparisons were done using Tukey's correction. Litter scores were analysed using $\chi^{2}$ analysis in SAS. Differences were considered significant when $P<0.05$ and $P<0 \cdot 10$ indicated a statistical trend.

\section{Results}

\section{Bone mineral status}

At day 4, tibia ash content decreased with the reduction of $\mathrm{P}$ and $\mathrm{Ca}$ in the diet $(-6 \%, P=0 \cdot 04$; Fig. 1). At day 8 , birds receiving the $\mathrm{L}$ diet between 5 and $8 \mathrm{~d}$ of age (HL and LL treatments) had a lower tibia ash content compared with control birds with the HH treatment (respectively, -4.46 and $-4.65 \%, P=0 \cdot 005)$. Birds receiving LH returned to the level of $\mathrm{HH}$ at day 8. At day 18 and day 33, no difference in tibia ash content was observed between the experimental groups.

At day 33, the tibia bone mineral density was lower with the LLHL treatment compared with the control treatment $(P=$ 0.045; Table 4). Tibia cortical bone mineral density also tended to be reduced with LLHL treatment compared with HLLL treatment $(P=0 \cdot 081)$. Otherwise, the different depletion-repletion strategies did not affect bone mineral criteria compared with control birds.

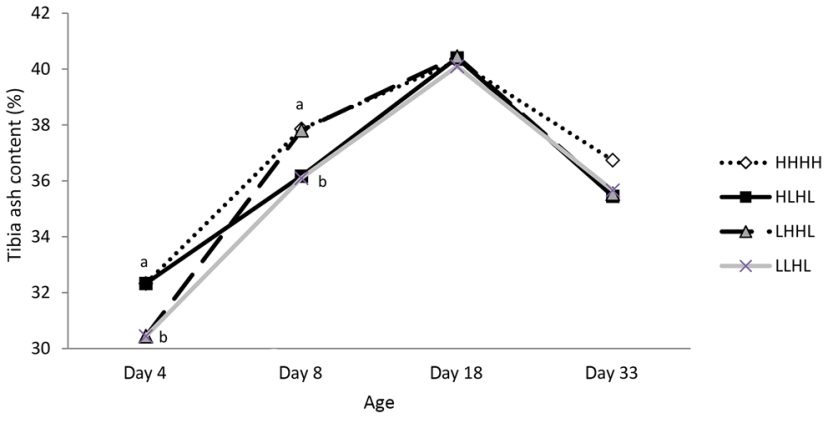

Fig. 1. Effect of calcium and non-phytate phosphorus (nPP) diet content on tibia ash content at day $4(\mathrm{H} v$. L diets from 0 to $4 \mathrm{~d})$, day $8(\mathrm{HH}$ and $\mathrm{LH} v$. $\mathrm{HL}$ and $\mathrm{LL}$ diets from 4 to $8 \mathrm{~d})$, day $18(\mathrm{HHH}, \mathrm{LHH}, \mathrm{HLH}$ and LLH diets from 8 to $18 \mathrm{~d}$ ) and day $33(\mathrm{HHHH}, \mathrm{LHHL}, \mathrm{HLHL}$ and LLHL diets from 18 to $33 \mathrm{~d}$ ). Values are means $(n 12) .{ }^{a, b}$ Least-square mean values within a sampling day with unlike letters were significantly different $(P<0.05) . \mathrm{H}$, diet high in $\mathrm{nPP}$ and calcium; $\mathrm{L}$, diet low in $\mathrm{nPP}$ and calcium.

\section{Digestibility of phosphorus and calcium and mRNA and protein expression of their transporters}

At day 8 , the AID of $\mathrm{P}$ and $\mathrm{Ca}$ as well as PPdisp were higher for birds receiving the $\mathrm{L}$ diet between 5 and $8 \mathrm{~d}$ of age (HL and LL compared with $\mathrm{HH}$ and $\mathrm{LH}, P \leq 0 \cdot 001, P \leq 0 \cdot 001$ and $P=0 \cdot 002$, respectively; Table 5). In parallel, there was a higher mRNA expression of CALB1 in birds with the LL diet compared with birds receiving $\mathrm{HH}$ or LH diets $(P \leq$ $0 \cdot 001)$. No effect was observed on the protein expression of $\mathrm{P}$ transporters or $\mathrm{Ca}$ transporters $(P>0 \cdot 05)$. At days 18 and 33 , diets did not affect $\mathrm{P}$ AID or mRNA and protein expression of transporters (Tables 6 and 7). At days 18 and 33, Ca AID was not affected by treatments $(P>0 \cdot 05)$.

\section{Growth performance}

Diets did not affect BW, average daily gain, average daily feed intake or mortality (Table 8). Pododermatitis scores (results not shown) were also not different among treatments. Retention efficiency of $\mathrm{P}$ was higher with the depletionrepletion strategies compared with control diets $(P=0.002)$, which resulted in lower litter $\mathrm{P}$ contents $(P=0 \cdot 008$; Table 8$)$.

\section{Discussion}

\section{Optimal timing and duration of the first depletion}

One of the objectives of the experiment was to study the best timing (from 0 to $4 \mathrm{~d}$ of age $v$. from 5 to $8 \mathrm{~d}$ of age $v$. from 0 to $8 \mathrm{~d}$ of age) and duration ( $4 \mathrm{~d} v .8 \mathrm{~d}$ ) of the initial depletion to induce a permanent adaptation in the birds. The treatments built to answer this question were LHHL, HLHL and LLHL. As expected, a decrease in nPP and Ca content in the diet between 0 and $4 \mathrm{~d}$ of age, 5 and $8 \mathrm{~d}$ of age or 0 and $8 \mathrm{~d}$ of age decreased bone mineral status during the corresponding phase, regardless of the diets received previously. At day 4 and day 8 , our results showed a lower tibia ash content in birds with low $\mathrm{P}$ and $\mathrm{Ca}$ content in the diet, as in Ashwell \& Angel $^{(11)}$ for toe ash content. These results agreed with those of Faridi et al. ${ }^{(18)}$, who observed by meta-analysis 
Table 4. Effect of calcium and non-phytate phosphorus (nPP) on tibia mineralisation at day 33 (Least-square mean values and pooled standard errors)

\begin{tabular}{lllllr}
\hline Dietary treatments* $\ldots$ & HHHH & HLHL & LHHL & LLHL & SEM \\
\hline$n$ & 10 & 10 & 10 & 10 & \\
Total bone BMD $\left(\mathrm{g} / \mathrm{cm}^{3}\right)$ & $1.311^{\mathrm{a}}$ & $1.298^{\mathrm{a}, \mathrm{b}}$ & $1.304^{\mathrm{a}, \mathrm{b}}$ & $1.297^{\mathrm{b}}$ & 0.010 \\
Trabecular bone BMD $\left(\mathrm{g} / \mathrm{cm}^{3}\right)$ & 1.225 & 1.223 & 1.225 & 1.225 & 0.003 \\
Cortical bone BMD $\left(\mathrm{g} / \mathrm{cm}^{3}\right)$ & 1.642 & 1.623 & 1.644 & 1.613 & 0.045 \\
\hline
\end{tabular}

$\mathrm{H}$, high $\mathrm{nPP}$ and $\mathrm{Ca}$; L, low $\mathrm{nPP}$ and $\mathrm{Ca}$; BMD, bone mineral density.

$\mathrm{a}, \mathrm{b}$ Least-square mean values within a row with unlike superscript letters were significantly different $(P<0.05)$.

* See Table 2.

Table 5. Effect of calcium and non-phytate phosphorus (nPP) on the apparent ileal digestibility (AID) of calcium and phosphorus, the ileal disappearance of phytate phosphorus (PPdisp) and normalised relative abundance of transporter mRNA at day 8

(Least-square mean values and pooled standard errors)

\begin{tabular}{|c|c|c|c|c|c|c|}
\hline Dietary treatments*... & $\mathrm{HH}$ & $\mathrm{HL}$ & $\mathrm{LH}$ & LL & SEM & $P$ \\
\hline$n$ & 8 & 8 & 16 & 16 & & \\
\hline Ca AID (\%) & $22 \cdot 72^{\mathrm{b}}$ & $46 \cdot 78^{a}$ & $22 \cdot 07^{\mathrm{b}}$ & $49 \cdot 64^{a}$ & 1.69 & $<0.001$ \\
\hline P AID (\%) & $48 \cdot 34^{\mathrm{b}}$ & $55 \cdot 68^{a}$ & $47 \cdot 16^{b}$ & $56 \cdot 57^{\mathrm{a}}$ & 1.08 & $<0.001$ \\
\hline PPdisp (\%) & $23 \cdot 07^{\mathrm{b}}$ & $31 \cdot 84^{\mathrm{a}}$ & $19 \cdot 35^{\mathrm{b}}$ & $33.19^{a}$ & $2 \cdot 79$ & 0.002 \\
\hline \multicolumn{7}{|l|}{ mRNA expression } \\
\hline$n$ & 12 & 12 & 12 & 12 & & \\
\hline Calb1 & $0.76^{\mathrm{b}}$ & $1.06^{a, b}$ & $0.92^{b}$ & $1 \cdot 34^{a}$ & 0.09 & $<0.001$ \\
\hline ATP2B1 & 0.96 & $1 \cdot 12$ & 0.93 & $1 \cdot 11$ & 0.09 & 0.248 \\
\hline SLC8A1 & 0.84 & $1 \cdot 26$ & 0.85 & 1.45 & 0.28 & 0.321 \\
\hline SLC34A2 & 0.91 & 0.96 & 0.96 & $1 \cdot 19$ & 0.10 & 0.213 \\
\hline SLC20A1 & $1 \cdot 26$ & $1 \cdot 26$ & 1.60 & $1 \cdot 37$ & 0.15 & 0.327 \\
\hline \multicolumn{7}{|l|}{ Protein expression } \\
\hline$n$ & 6 & 6 & 6 & 6 & & \\
\hline Calb1 & $1 \cdot 31$ & $1 \cdot 32$ & 0.70 & $0 \cdot 79$ & 0.86 & 0.453 \\
\hline SLC20A1 & $2 \cdot 23$ & 0.82 & $1 \cdot 37$ & 0.79 & $2 \cdot 08$ & 0.081 \\
\hline
\end{tabular}

$\mathrm{H}$, high nPP and Ca; L, low nPP and Ca.

a,b Least-square mean values within a row with unlike superscript letters were significantly different $(P<0.05)$.

* See Table 2.

that $4.0 \mathrm{~g} / \mathrm{kg} \mathrm{nPP}$ are needed to obtain optimal bone mineralisation until $21 \mathrm{~d}$ of age, with $7 \cdot 0 \mathrm{~g} / \mathrm{kg} \mathrm{Ca}$ and $2000 \mu \mathrm{g} / \mathrm{kg}$ of vitamin $\mathrm{D}_{3}$.

Birds receiving a diet low in $\mathrm{P}$ and $\mathrm{Ca}$ increased their $\mathrm{P}$ and Ca AID at day 8, but showed lower bone mineralisation than the controls, as observed by Rousseau $e t$ al. ${ }^{(1)}$. At day 8 , this

Table 6. Effect of calcium and non-phytate phosphorus (nPP) on the apparent ileal digestibility (AID) of calcium and phosphorus and normalised relative abundance of transporter mRNA at day 18 (Least-square mean values and pooled standard errors)

\begin{tabular}{lrrrrrr}
\hline Dietary treatments* $\ldots$ & HHH & HLH & LHH & LLH & SEM & $P$ \\
\hline$n$ & 8 & 8 & 8 & 16 & & \\
Ca AID (\%) & 35.05 & 34.77 & 34.81 & 37.36 & 4.94 & 0.804 \\
P AID (\%) & 51.62 & 51.75 & 50.49 & 53.81 & 3.61 & 0.431 \\
mRNA expression & & & & & & \\
$\quad n$ & 12 & 12 & 12 & 12 & & \\
$\quad$ Calb1 & 0.95 & 0.91 & 1.00 & 0.99 & 0.29 & 0.440 \\
$\quad$ ATP2B1 & 1.17 & 1.03 & 1.06 & 1.17 & 0.35 & 0.657 \\
$\quad$ SLC8A1 & 0.25 & 0.23 & 0.15 & 0.16 & 0.15 & 0.559 \\
$\quad$ SLC34A2 & 0.94 & 0.84 & 0.97 & 1.01 & 0.23 & 0.392 \\
$\quad$ SLC20A1 & 0.29 & 0.32 & 0.19 & 0.24 & 0.18 & 0.346 \\
Protein expression & & & & & & \\
$\quad n$ & 6 & 6 & 6 & 6 & & \\
$\quad$ Calb1 & 0.52 & 0.86 & 0.65 & 0.73 & 0.81 & 0.492 \\
$\quad$ SLC20A1 & 1.10 & 0.75 & 0.85 & 1.11 & 0.54 & 0.743 \\
\hline
\end{tabular}

$\mathrm{H}$, high nPP and Ca; L, low nPP and Ca.

* See Table 2. adaptation appeared to be limited to the diet received during the starter phase (day 5-8) regardless of the feed received during the pre-starter phase (days $0-4$ ) with HL and LL leading to similar results. For $\mathrm{Ca}$, this adaptation was linked to an increase of $C A L B 1$ gene expression. Increased AID of $\mathrm{Ca}$ linked to increased CALB1 gene expression ${ }^{(1)}$ was also

Table 7. Effect of calcium and non-phytate phosphorus (nPP) on the apparent ileal digestibility (AID) of calcium and phosphorus and normalised relative abundance of transporter mRNA and protein at day 33 (Least-square mean values and pooled standard errors)

\begin{tabular}{lrrrrrr}
\hline Dietary treatments ${ }^{*} .$. & HHHH & HLHL & LHHL & LLHL & SEM & $P$ \\
\hline$n$ & 8 & 8 & 8 & 8 & & \\
Ca AID (\%) & 23.84 & 24.19 & 17.71 & 19.37 & 8.32 & 0.347 \\
P AID (\%) & 39.27 & 39.74 & 37.11 & 38.54 & 7.62 & 0.918 \\
mRNA expression & & & & & & \\
$\quad n$ & 12 & 12 & 12 & 12 & & \\
$\quad$ Calb1 & 1.28 & 1.42 & 1.48 & 1.49 & 0.40 & 0.496 \\
$\quad$ ATP2B1 & 0.89 & 1.14 & 1.63 & 1.21 & 0.58 & 0.553 \\
$\quad$ SLC8A1 & 0.43 & 0.42 & 0.79 & 0.54 & 0.23 & 0.398 \\
$\quad$ SLC34A2 & 0.51 & 0.43 & 0.65 & 0.67 & 0.38 & 0.188 \\
$\quad$ SLC20A1 & 0.93 & 0.61 & 0.91 & 0.61 & 0.25 & 0.072 \\
Protein expression & & & & & & \\
$\quad n$ & 6 & 6 & 6 & 6 & & \\
Calb1 & 1.07 & 0.85 & 1.03 & 1.22 & 0.73 & 0.451 \\
$\quad$ SLC20A1 & 0.70 & 0.92 & 1.46 & 1.35 & 0.82 & 0.373 \\
\hline
\end{tabular}

$\mathrm{H}$, high $\mathrm{nPP}$ and $\mathrm{Ca}$; L, low $\mathrm{nPP}$ and $\mathrm{Ca}$.

* See Table 2. 
Table 8. Effect of calcium and non-phytate phosphorus (nPP) on growth performance of chickens from 0 to $33 \mathrm{~d}$ of age and litter quality and phosphorus retention efficiency at day 33

(Least-square mean values and pooled standard errors)

\begin{tabular}{|c|c|c|c|c|c|c|}
\hline Dietary treatments*. & $\mathrm{HHHH}$ & HLHL & LHHL & LLHL & SEM & $P$ \\
\hline$n$ & 8 & 8 & 8 & 8 & & \\
\hline $\operatorname{ADG}(g / d)$ & 64.56 & 63.99 & 65.65 & 65.45 & 1.91 & 0.420 \\
\hline ADFI $(g / d)$ & $92 \cdot 90$ & 92.99 & 95.05 & 94.59 & $2 \cdot 69$ & 0.344 \\
\hline FCR & 1.461 & 1.471 & 1.465 & 1.456 & 0.015 & 0.261 \\
\hline Mortality (\%) & $6 \cdot 89$ & 7.48 & $5 \cdot 27$ & $5 \cdot 22$ & 3.94 & 0.587 \\
\hline$n$ & 4 & 4 & 4 & 4 & & \\
\hline Litter DM day 33 (\%) & $48 \cdot 09^{a, b}$ & $42 \cdot 49^{\mathrm{a}}$ & $51.41^{b}$ & $48 \cdot 01^{a, b}$ & 4.14 & 0.035 \\
\hline Litter $P$ content $(\mathrm{mg} / \mathrm{g})$ & $10 \cdot 19^{\mathrm{a}}$ & $9 \cdot 00^{\mathrm{b}}$ & $8 \cdot 85^{\mathrm{b}}$ & $8 \cdot 19^{b}$ & 0.95 & 0.008 \\
\hline Litter Ca content $(\mathrm{mg} / \mathrm{g})$ & $13 \cdot 64^{\mathrm{a}}$ & $11.51 a^{b}$ & $11.86 \mathrm{a}^{\mathrm{b}}$ & $10 \cdot 75^{\mathrm{b}}$ & $1 \cdot 27$ & 0.001 \\
\hline $\mathrm{P}$ retention efficiency $(\%)$ & $50 \cdot 80^{b}$ & $59 \cdot 46^{a}$ & $57 \cdot 78^{\mathrm{a}}$ & $59 \cdot 31^{a}$ & 3.03 & 0.002 \\
\hline
\end{tabular}

$\mathrm{H}$, high nPP and $\mathrm{Ca}$; L, low nPP and Ca; ADG, average daily gain; ADFI, average daily feed intake; FCR, feed conversion ratio.

$\mathrm{a}, \mathrm{b}$ Least-square mean values within a row with unlike superscript letters were significantly different $(P<0.05)$.

* See Table 2 .

reported in chicks given a low-Ca diet for a 14-d period. Some authors also observed that a decrease of dietary $\mathrm{Ca}$ and $\mathrm{nPP}$ levels stimulated the mRNA expression of other $\mathrm{Ca}$ transporters: SLC8A1 and ATP2B1, and P transporters: SLC20A1 and $S L C 34 A 2^{(3,6,19)}$. Several facts could explain the discrepancy with our results. For the $\mathrm{Ca}$ transporters, $C A L B 1$ has been proven to be the rate-limiting step in $\mathrm{Ca}$ absorption through the epithelium, thus CALB1 expression is highly correlated with intestinal $\mathrm{Ca}$ absorption efficiency ${ }^{(20)}$. The lack of effect on protein expression could reflect previous observations that mRNA and protein expression for the same transporter exhibit different temporal patterns ${ }^{(5)}$. Moreover, most experiments find poor correlations between mRNA and protein abundances in the cell due to numerous posttranscriptional regulation mechanisms ${ }^{(21)}$.

As for the lack of effect on $\mathrm{P}$ transporter expression, Ca metabolism had been proven to be more closely regulated than $\mathrm{P}$ metabolism ${ }^{(22)}$. We hypothesise that $\mathrm{Ca}$ was the major mineral deficient in our experiment and drove regulation, thus explaining the lack of effect on P AID at day 18 and day 33 as well as on $\mathrm{P}$ transporter protein and mRNA expression. Moreover, $\mathrm{P}$ intake through $S L C 34 A 2$ was defined as the limiting step of $\mathrm{P}$ absorption in the intestine ${ }^{(9)}$. Thus, the regulation of $\mathrm{P}$ homeostasis would occur mainly by the stimulation of SLC34A2 expression. Yan et al. ${ }^{(7)}$ and Olukosi et al. ${ }^{(8)}$ showed that $\mathrm{P}$ content in the diet had to be at $0.25 \%$, lower than used in our $\mathrm{L}$ starter diets, in order to enhance the mRNA expression of SLC34A2. The regulation of $\mathrm{P}$ absorption could also be at the post-translational levels as suggested by Hattenhauer et al. ${ }^{(23)}$ in mice, with modifications such as glycosylation, ubiquination or palmitoylation. Alternatively, we could hypothesise that the highest P AID was not linked to a mechanism regulating $\mathrm{P}$ transporters, but rather to a mechanism regulating phytic $\mathrm{P}$ release through endogenous phytase activity. Phytic P hydrolysis being a major component of the P AID, the pre-caecal disappearance of phytic $\mathrm{P}$ was determined in order to better understand this effect. Phytic P disappearance at day 8 was higher for birds fed with the $\mathrm{L}$ diet between 5 and $8 \mathrm{~d}$ compared with birds fed with the $\mathrm{H}$ diet, suggesting an increase in endogenous phytase activity. Onyango et al. ${ }^{(2)}$ observed that the activity of mucosal endogenous phytase increased with a reduction of the P content $(1.2 v .4 .6 \mathrm{~g} / \mathrm{kg}$ of $\mathrm{nPP})$ and the supplementation of cholecalciferol $(0 v .3320 \mu \mathrm{g} / \mathrm{kg})$ in the diet.

\section{Response to a second depletion}

It is possible to lower nPP and Ca content in the diet through all phases without affecting growth performance or mortality. Akter et al. ${ }^{(25)}$ also observed that $\mathrm{Ca}$ and nPP content could be reduced (respectively, 6.0 and $3.0 \mathrm{~g} / \mathrm{kg}$ from 0 to $35 \mathrm{~d}$ of age) without affecting feed conversion ratio. Delezie et al. ${ }^{(26)}$ observed similar results with a reduction of $20-25 \%$ of $\mathrm{Ca}$ and $\mathrm{nPP}$ dietary contents compared with commercial diets throughout the growth cycle. This result could potentially be explained by the fact that the recommendations are generally set to maximise bone ssh $^{(27)}$ which are higher than for growth as reported in a meta-analysis by Faridi et al. ${ }^{(18)}$.

We hypothesised that birds who had been previously depleted could react better to a second depletion occurring in the finisher phase. A second depletion did not have an impact on bone mineral status. At the end of the finisher phase, no differences in mineral AID were observed between the diets, regardless of the initial period and duration of depletion (see treatments LHHL, HLHL and LLHL). P and Ca depletion in an early phase did not induce a permanent adaptation of $\mathrm{P}$ and/or $\mathrm{Ca}$ transporter genes, protein expression or growth performance contrary to expectations. It is worth noting that the AID of Ca at day 33 was particularly low. Such low values were previously observed in finisher broilers ${ }^{(1)}$. There is no consensus methodology to assess $\mathrm{Ca}$ digestibility and there are frequently inconsistencies through measurements ${ }^{(28)}$. In particular, Ca digestibility is reduced with age in broilers ${ }^{(29)}$. Future studies are needed to understand the reasons for the low digestibility values observed with the direct method used here, among them, the effects of dietary $\mathrm{P}$ concentrations and $\mathrm{Ca}: \mathrm{P}$ ratios on $\mathrm{Ca}$ digestibility, the indigestible marker, reverse peristalsis, will be relevant to study. Likewise, Van Krimpen et al. (unpublished results) found that birds depleted from 0 to $4 \mathrm{~d}$ of age and receiving a control diet from 5 to $37 \mathrm{~d}$ of age had the same SLC34A2,CALB1 and ATP2B1 gene expression as control birds at day 21 and day 37. 
Conversely, other authors have demonstrated that the implementation of a permanent adaptation was possible. Rousseau et al. ${ }^{(1)}$ observed that birds fed with an $\mathrm{L}$ diet $(0.60 \% \mathrm{Ca}$ and $0.24 \%$ available $\mathrm{P}$ ) between 10 and $21 \mathrm{~d}$ of age and replenished with an $\mathrm{H}$ diet $(0.90 \% \mathrm{Ca}$ and $0.28 \%$ available $\mathrm{P})$ between 22 and $35 \mathrm{~d}$ of age had higher $\mathrm{Ca}$ and P AID at day 35 compared with birds fed with diets at recommendations from 10 to $35 \mathrm{~d}$ of age. Ashwell \& Angel $^{(11)}$ observed that birds depleted during the first $90 \mathrm{~h}$ of life had a higher P AID when depleted a second time between day 22 and day 38. These authors used a Ca:nPP ratio of 1.64 in the $\mathrm{L}$ diet between 0 and $4 \mathrm{~d}$ of age, in contrast to $2 \cdot 14$ in the present experiment. The $\mathrm{Ca}$ and available $\mathrm{P}$ contents in the diet between 0 and $4 \mathrm{~d}$ of age used by Ashwell \& Angel ${ }^{(11)}$ were, respectively, 0.59 and $0.25 \%$ compared with 0.77 and 0.36 $\%$ in the present experiment. Birds were thus probably more deficient in $\mathrm{P}$ than in our experiment. Consequently, it could be hypothesised that $\mathrm{P}$ deficiency probably is the inducer of the permanent adaptation.

A decrease in dietary $\mathrm{Ca}$ and $\mathrm{nPP}$ has been shown to induce regulation in the kidney and bones ${ }^{(3)}$. The expression of $\mathrm{Ca}$ and $\mathrm{P}$ transporters in the kidney is increased to enhance the $\mathrm{Ca}$ and $\mathrm{P}$ renal reabsorption and bone resorption is stimulated to release $\mathrm{P}$ and $\mathrm{Ca}^{(6)}$. A long-term adaptation to the early depletion might have occurred in our experiment in the kidney and bones. Indeed, P retention efficiency was higher for birds that received depletion-repletion treatments while no effect was seen on $\mathrm{P}$ AID at day 18 and day 33. The higher $\mathrm{P}$ retention efficiency could be linked to higher renal reabsorption of $\mathrm{P}$ or increased bone turnover rather than a change in digestibility/absorption.

In the present experiment, we did not observe a long-term adaptation of the animals to an early depletion, while $\mathrm{P}$ retention efficiency was around $51 \%$ in the control diet. Van Krimpen et al. (unpublished results) also did not observe a long-term adaptation with similar P retention efficiency values. In contrast, Ashwell \& Angel ${ }^{(11)}$ observed that birds depleted during the first $90 \mathrm{~h}$ of life exhibited higher $\mathrm{P}$ absorption at $38 \mathrm{~d}$ compared with control birds when both groups were fed with a low finisher diet. The $\mathrm{P}$ retention efficiency in this study was $35.3 \%$ in the control diet, compared with $47.1 \%$ in the low pre-starter diet accompanied by a higher total P intake for the control birds $(11.9 \mathrm{~g} / \mathrm{kg} \mathrm{BW})$. As suggested by Van Krimpen et al. (unpublished results) the apparent long-term adaptation observed by Ashwell \& Angel $^{(11)}$ could result from a reduced $\mathrm{P}$ retention efficiency in the control diet rather than an enhancement resulting from the depletion during the pre-starter phase.

\section{Necessity of a repletion}

One of our preliminary hypotheses was that a repletion phase was necessary in order to catch up in bone mineralisation. Birds depleted from 0 to $4 \mathrm{~d}$ of age had the same bone mineral status at day 8 compared with control birds when fed with the $\mathrm{H}$ diet between 5 and $8 \mathrm{~d}$ of age. Likewise, birds depleted from 0 to $8 \mathrm{~d}$ of age or 5 to $8 \mathrm{~d}$ of age showed similar bone criteria at day 18 compared with control diets, when replenished between 9 and $18 \mathrm{~d}$ of age. The birds seemed to be able to catch up in bone mineralisation after 4 or $8 \mathrm{~d}$ on a control diet. Whatever the type of initial depletion, repletion with the $\mathrm{H}$ diet led to similar $\mathrm{P}$ and $\mathrm{Ca}$ AID at $18 \mathrm{~d}$ of age. As a result, higher $\mathrm{Ca}$ and $\mathrm{nPP}$ content in the diet was the explanation of a catch up in bone mineralisation rather than a permanent adaptation of birds to increase $\mathrm{P}$ and $\mathrm{Ca}$ digestive utilisation.

In the finisher phase, the birds were able to maintain a mineral status at the control levels when fed the L diet. It had been demonstrated that $\mathrm{P}$ and $\mathrm{Ca}$ requirements for bone growth and metabolism decrease with age ${ }^{(30)}$ and the dietary $\mathrm{Ca}$ and $\mathrm{nPP}$ content were reduced accordingly in our experiment. Moreover, the decrease in $\mathrm{nPP}$ and Ca dietary content was less severe for the birds during the finisher phases 1 and 2 (respectively, -21 and $-25 \%$ compared with $-30 \%$ during the pre-starter and starter phase). Interestingly, the most depleted programme, LLHL, led to lower tibia bone mineral density without effects on tibia ash content. Bone mineral content discriminated between the dietary treatments with more sensitivity than classical bone measures as seen in Angel et al. ${ }^{(31)}$ and Bradbury et al. ${ }^{(22)}$. Interestingly, cortical bone mineral density followed the same trend to discriminate between the treatments compared with total bone mineral density. However, trabecular bone mineral density was not affected by dietary treatment. Likewise, Kim et al. ${ }^{(32)}$ and Jendral et al. ${ }^{(33)}$ found that total and cortical bone mineral density discriminated between the treatments with no effect on trabecular bone mineral density in, respectively, broiler chicks at day 21 and hens at 65 weeks of age. As stated by these authors, these results could be due to excessive bone resorption from the endosteal surface located at the inner edge of the cortical shell. The analysed feed composition showed that the Ca: $\mathrm{nPP}$ ratio in the $\mathrm{L}$ diet during the finisher phase was $2.65 \mathrm{com}-$ pared with 2.20 as formulated. As a result, the Ca intake compared with the nPP intake was much higher than formulated during this phase. The higher ratio could reduce $\mathrm{P}$ availability and then increase bone resorption.

\section{Conclusion}

Reducing $\mathrm{P}$ and $\mathrm{Ca}$ content in the diet did not have an impact on growth performance. Despite reduced bone mineralisation during the initial depletion phase, the birds were able to catch up in bone mineralisation at day 8 or at day 18, after being fed a diet at commercial $\mathrm{Ca}$ and nPP levels during, respectively, the starter or grower phase. It is then possible to lower nPP and $\mathrm{Ca}$ in the diet during the finisher period, without affecting growth performance or bone mineralisation. Our results demonstrated that it was not necessary to replenish the diets during the finishing period in order to ensure acceptable bone mineralisation, thus limiting the environmental impact of the production. The birds adapted to a diet low in $\mathrm{P}$ and $\mathrm{Ca}$ content by increasing their $\mathrm{P}$ and $\mathrm{Ca}$ AID accompanied by stimulation of the mRNA expression of the $\mathrm{Ca}$ transporter, CALB1. This adaptation appeared to be limited to the starter phase for birds receiving the depleted diet. None of our initial depletion strategies led to a long-lasting adaptation. All of the depletion-repletion strategies used improved litter quality. However, the LLHL programme showed the most promising 
results, with optimal growth performance and the largest decrease in environmental and economic impacts.

\section{Acknowledgements}

The authors gratefully acknowledge PEAT INRA Poultry Experimental Facility (2018, https://doi.org/10.15454/1. 5572326250887292E12) for conducting the animal experiment. We are grateful to the CIRE platform for their technical support in performing the laboratory analysis.

The present study was supported by a CRD research grant from NSERC, with Nutreco Canada, Prorec, Aliments Breton, and MixScience as industry partners.

The contributions of each author to the study were as follows: A. S. V., A. N., S. K., G. P. and M. P. L.-M. participated in the design and planning of the study; A. S. V., L. L., F. L., S. M.-C. and N. M. participated in the laboratory analysis of the data; A. S. V., A. N. and M. P. L.-M. participated in the analysis and interpretation of the data; A. S. V., A. N., M. J. D., F. L., S. K., G. P. and M. P. L.-M. participated in the writing and editing of the article.

There are no conflicts of interest.

\section{References}

1. Rousseau X, Valable AS, Létourneau-Montminy MP, et al. (2016) Adaptive response of broilers to dietary phosphorus and calcium restrictions. Poult Sci 95, 2849-2860.

2. Yan F, Angel R, Ashwell C, et al. (2005) Evaluation of the broiler's ability to adapt to an early moderate deficiency of phosphorus and calcium. Poult Sci 84, 1232-1241.

3. Proszkowiec-Weglarz M \& Angel R (2013) Calcium and phosphorus metabolism in broilers: effect of homeostatic mechanism on calcium and phosphorus digestibility. J Appl Poult Res 22, 609-627.

4. Nie W, Yang Y, Yuan J, et al. (2012) Effect of dietary non-phytate phosphorus on laying performance and small intestinal epithelial phosphate transporter expression in dwarf pink-shell laying hens. J Anim Sci Biotechnol 4, 34.

5. Cai Q, Chandler JS, Wasserman RH, et al. (1993) Vitamin D and adaptation to dietary calcium and phosphate deficiencies increase intestinal plasma membrane calcium pump gene expression. Proc Nat Acad Sci U S A 90, 1345-1349.

6. Centeno VA, Diaz de Barboza GA, Marchionattia AN, et al. (2004) Dietary calcium deficiency increases $\mathrm{Ca}^{2+}$ uptake and $\mathrm{Ca}^{2+}$ extrusion mechanisms in chick enterocytes. Comp Biochem Phys A 139, 133-141.

7. Yan F, Angel R \& Ashwell CM (2007) Characterization of the chicken small intestine type IIb sodium phosphate cotransporter. Poult Sci 86, 67-76.

8. Olukosi O, Adedokun SA, Ajuwon KM, et al. (2011) Early responses of sodium-dependent phosphate transporter type IIb in broiler chicks to dietary phosphorus intervention. Br Poult Abstr 7, 39.

9. Huber K, Zeller E \& Rodehutscord M (2015) Modulation of small intestinal phosphate transporter by dietary supplements of mineral phosphorus and phytase in broilers. Poult Sci 94, 1009-1017.

10. Fang R, Xiang Z, Cao M, et al. (2012) Different phosphate transport in the duodenum and jejunum of chicken response to dietary phosphate adaptation. Asian-Aust J Anim Sci 25, 1457-1465.

11. Ashwell CM \& Angel R (2010) Nutritional genomics: a practical approach by early life conditioning with dietary phosphorus. $R$ Bras Zootec 39, 268-278.

12. Cobb-Vantress (2015) Performances et recommandations nutritionnelles Cobb500 ${ }^{\mathrm{TM}}$ (Nutritional performance and recommendations Cobb500 $\left.{ }^{\mathrm{TM}}\right)$. https://www.cobb-vantress.com/fr_FR/products/cobb 500/ (accessed June 2020).
13. Militist G, Donkó T, Dalle Zotte A, et al. (2013) Application of computed tomography to assess the effect of egg yolk ratio on body composition in chickens of different genotypes and gender at hatch and during the rearing period. Br Poult Sci 54, 611-619.

14. Sherlock ML, Demmers TGM, Goodship AE, et al. (2010) The relationship between physical activity and leg health in the broiler chickens. Br Poult Sci 51, 22-30.

15. Jonchere V, Brionne A, Gautron J, et al. (2012) Identification of uterine ion transporters for mineralisation precursors of the avian eggshell. BMC Physiol 12, 10.

16. Coudert E, Pascal G, Dupont J, et al. (2015) Phylogenesis and biological characterization of a new glucose transporter in the chicken (Gallus gallus), GLUT12. PLOS ONE 10, e0139517.

17. SAS Institute Inc. (2003) Statistical Analysis System, version 9.0. Cary, NC: SAS Institute Inc.

18. Faridi A, Gitoee A \& France J (2015) A meta-analysis of the effects of non-phytate phosphorus on broiler performance and tibia ash concentration. Poult Sci 94, 2753-2762.

19. Bar A (2009) Calcium transport in strongly calcifying laying birds: mechanisms and regulation. Comp Biochem Phys A 152, 447-469.

20. Joost G, Hoenderop J, Nilius B, et al. (2005) Calcium absorption across epithelia. Physiol Rev 85, 373-322.

21. Maier T, Güell M \& Serrano L (2009) Correlation of mRNA and protein in complex biological samples. FEBS Lett 583, 3966-3973.

22. Bradbury EJ, Wilkinson SJ, Cronin GM, et al. (2014) Nutritional geometry of calcium and phosphorus in broiler chicks. Growth performance, skeletal health and intake arrays. Animal 8, 1071-1079.

23. Hattenhauer O, Traebert M, Murer H, et al. (1999) Regulation of small intestinal Na-Pi type IIb cotransporter by dietary phosphate intake. Am J Physol Gastrointest Liver Physiol 277, 756-762.

24. Onyango EM, Asem EK \& Adeola O (2007) Dietary cholecalciferol and phosphorus influence intestinal mucosa phytase activity in broiler chicks. Br Poult Sci 47, 632-639.

25. Akter M, Graham H \& Iji PA (2016) Response of broiler chickens to different levels of calcium, non-phytate phosphorus and phytase. Br Poult Sci 57, 799-809.

26. Delezie E, Bierman K, Nollet L, et al. (2015) Impacts of calcium and phosphorus concentration, their ratio, and phytase supplementation level on growth performance, foot pad lesions, and hock burn of broiler chickens. J Appl Poult Res 24, 115-126.

27. Driver JP, Pesti GM, Bakalli RI, et al. (2006) The effect of feeding calcium- and phosphorus-deficient diets to broiler chickens during the starting and growing-finishing phases on carcass quality. Poult Sci 85, 1939-1946.

28. Anwar N \& Ravindran V (2016) Measurement of calcium digestibility in feed ingredients for poultry - methodology and challenges. In Phytate Destruction: Consequences for Precision Animal Nutrition, pp. 191206 [CL Walk, I Kühn, HH Stein, MT Kidd and M Rodehutscord, editors]. Wageningen: Wageningen Academic Publishers.

29. Angel R, Proszkowiec-Weglarz M, Jimenez-Moreno E, et al. (2013) Impact of time and dietary calcium and phosphorus deficiencies on their digestibilities in single ingredients. Proceedings of the European Symposium of Poultry Nutrition, Potsdam, Germany.

30. Li J, Yuan J, Miao Z, et al. (2017) Effects of age on intestinal phosphate transport and biomechanical values of broiler chickens. Asian-Aust J Anim Sci 30, 221-228.

31. Angel R, Saylor WW, Mitchell AD, et al. (2006) Effect of dietary phosphorus, phytase and 25-hydroxycholecalciferol on broiler chicken bone mineralization, litter phosphorus and processing yields. Poult Sci 85, 1200-1211.

32. Kim WK, Bloomfield SA \& Ricke SD (2011) Effects of age, vitamin $\mathrm{D}_{3}$, and fructooligosaccharies on bone growth and skeletal integrity of broiler chicks. Poult Sci 90, 2425-2432.

33. Jendral MJ, Korver DR, Church JS, et al. (2008) Bone mineral density and breaking strength of white leghorns housed in conventional, modified, and commercially available colony battery cages. Poult $S_{c i}$ 87, 828-837.

34. National Research Council (1994) Nutrient Requirements of Poultry, 9th revised ed. Washington, DC: The National Academies Press. 